\title{
EUROPEAN LAW IN THE EMPIRES OF MECHANICAL JURISPRUDENCE: THE JUDICIAL APPLICATION OF EUROPEAN LAW IN CENTRAL EUROPEAN CANDIDATE COUNTRIES
}

\author{
Zdeněk Kühn*
}

Summary: The process of European enlargement had a peculiar nature. Prior to accession in 2004, EU law was not yet formally binding on EU candidates' domestic courts, while the obligation of gradual harmonisation with EU law rested upon them. Consequently, the application of EU law in future Member States presented particularly interesting problems and challenges, and required an understanding of the sophisticated concept of EU law's persuasive force. The only rational choice was to apply Community law, taking into account not only the limited scope of the legislative texts for harmonisation, but also Community law in its full meaning. This included the texts of European directives, which had to be transposed into domestic law, as well as their reasoning and rationale, which would explain why a particular policy was regulated at the European level; ECJ jurisprudence; and, ideally, also the case law of EU Member States. This article argues that this involves a special type of use of comparative law.

\section{The use of EU law in associated states as a theoretical problem}

Poland, Slovakia and the Czech Republic modified their constitutions prior to 1 May 2004 in order to facilitate their EU accession and transfer some of their sovereign powers to the EU. ${ }^{1}$ However, their relations with the EU were based on association agreements before the Enlargement. At the same time, their association agreements formed the bulk of ordinary international treaty law, while the use of the association agreements in Central Europe was governed by the national constitutions and the clauses on the relation between municipal and international law.

All Central European countries were obliged to remodel their legal systems and make them gradually compatible with the acquis communautaire. ${ }^{2}$ All things considered, it would be ineffective to approach the obligations flowing from association agreements like an ordinary international treaty. First, European law

\footnotetext{
-Zdenek Kühn, Assistant Professor, Charles University Law School, Prague, Czech Republic. Ph.D., Charles University Law School (2001); LL.M., University of Michigan Law School (2002); S.J.D. Candidate, University of Michigan Law School (2003). I owe thanks to Eric Stein and Mathias Reimann of the University of Michigan Law School, Siniša Rodin and Tamara Ćapeta of the Faculty of Law of the University of Zagreb, and Peter Th Ørebech of the Tromsø Law School for their comments and to the Václav Havel Graduate Fellowship of the University of Michigan for its financial support. Responsibility for any errors rests with me. This article is an extended and further developed version of an article published in 28 ELRev. 551 (2003).

${ }^{1}$ See particularly Art. 90 of the Polish Constitution of 1997, Art. 10a of the Czech Constitution effective as of June 1, 2002 and Art. 7(2) of the Slovak Constitution (as amended in 2001). For the Polish Constitution in this relation, see primarily Wójtowicz, Proposed Changes in the Polish Constitution of 1997 ahead of Poland's Accession to the European Union (2001) 25 Polish Yearbook of International Law, p. 27.

${ }^{2}$ On this, see Laffranque \& D'Sa, Domestic implementation of E.U. Regulations in Estonia: a flawed methodology or necessary transposition? (2002) 27 ELRev. p. 91; Evans, Voluntary Harmonisation in Integration between the European Community and Eastern Europe (1997) 22 ELRev. p. 201, particularly p. $203 \mathrm{ff}$.
} 
served as a model in legislation. EU law, however, should also be used as an argumentative tool for the consistent interpretation of domestic law with EU law. Since EU law was not formally binding within the associated states, the very nature of association seemed to call for a sophisticated concept of a strong persuasive source of law. ${ }^{3}$ Below, I will argue that the use of EU law in the application of domestic law before the accession was a special type of use of comparative law in the interpretation of domestic law in the associated states.

\section{I.1 Obligatory Use of Comparative Law}

Ulrich Drobnig distinguished three categories of use of comparative law when interpreting domestic law. ${ }^{4}$ The first is the use of comparative law which might be considered obligatory. This is followed by the non-obligatory but highly recommended use of foreign law in cases with a foreign element. Finally, and conceptually most interesting, there is comparative argumentation in cases with a purely domestic character.

Obligatory comparative reasoning relates to the cases where comparison is necessary, because "recourse to foreign law and in some cases even true comparison is inevitable for the proper application of the rules". An important example at the EU level is the use of general legal principles of member states when the ECJ interprets EU law. ${ }^{6}$ The national legal systems here play a dual role: on the one hand formally a foreign law to the European Court, on the other hand an auxiliary source of EU law, assuring the open and dynamic nature of EU law. ${ }^{7}$ For instance, Art. 288(2) of the EC Treaty proclaims that the non-contractual liability of the EC shall be determined "in accordance with the general principles common to the laws of member states". 8 Another example is the comparatively conceived conception of human rights within the area of EU law, based on "constitutional traditions common to the Member States".

\footnotetext{
${ }^{3}$ Generally Glenn, Persuasive Authority (1987) 32 McGill Law Journal p. 261.

${ }^{4}$ Drobnig, General Report, In: Drobnig and van Erp (eds.) The Use of Comparative Law by Courts (1997) The Hague/London/Boston: Kluwer Law International, p. 1 ff. I follow and modify this classification for the purpose of my paper.

${ }^{5}$ Ibid., at 6.

${ }^{6}$ Cf. recently Lenaerts, Interlocking Legal Orders or the European Union Variant of 'E Pluribus Unum', in: Nafziger, Symeonides (eds.), Law and Justice in a Multistate World (, (2002) Transnational Publishers, New York, p. 751-778. Comparative law is not argumentation by the general or fundamental principles of EU law, which are the product of EU law proper, i.e. EU primary and secondary law. To identify various types of these principles, cf. Tridimas, The General Principles of EC LAw (1999) Oxford University Press, Oxford, at $3 \mathrm{ff}$. Cf. also the distinction clearly postulated by the ECJ itself, when this court proclaimed that in its decision-making it decides 'in accordance with the generally accepted methods of interpretation, in particular by reference to the fundamental principles of the Community legal system and, where necessary, general principles common to the legal principles of the Member States.' Joined cases C-46/93 and C-48/93, Brasserie du Pêcheur SAv Bundesrepublik Deutschland and The Queen $v$ Secretary of State for Transport, ex parte: Factortame Ltd and others [1996] European Court Reports I-1029, para. 27. Only the latter (general principles common to the Member States) means the use of comparative law proper.

${ }^{7}$ Cf. Bengoetxea, The Legal Reasoning of the European Court of Justice. Towards a European Jurisprudence. (1993) Clarendon Press, Oxford, at 79. On this method in the ECJ's jurisprudence recently, cf. Lenaerts, see n.6 (claiming that comparative law 'plays a central role' at the ECJ and the Court of First Instance).

${ }^{8}$ Generally Kiikeri, Comparative Legal Reasoning and European Law (2001) Dordrecht/ Boston/ London: Kluwer Academic Publishers, or Koopmans, Comparative Law and the Courts (1996) 45 International and Comparative Law Quarterly p. 545. The use of general principles of law within EU law is not limited to the articles that explicitly refer to those principles. See the following note.
} 
A third example is the use of the case law of signatories to an international treaty, interpreting the treaty if the treaty is applied within the national legal system and is part of the "law of the land". ${ }^{10}$ A national judge interpreting international law must take into account the way international rule is interpreted by the courts of foreign nations. ${ }^{11}$ Art. 7(1) of the Convention of International Sale of Goods in this regard emphasises that "[i]n the interpretation of this Convention, regard is to be had to its international character and to the need to promote uniformity in its application and the observance of good faith in international trade."12 For instance, the United States Supreme Court remarked that in interpreting a problematic term of an international treaty "we find the opinions of our sister signatories to be entitled to considerable weight." "13

\section{I.2 Non-obligatory Use of Foreign Law in Cases with an International Element}

The other two groups lack the "necessary" comparative feature of judicial reasoning. The second group, however, still has a foreign or international element. In spite of that, the comparison is not mandatory, but in specific cases it would often be highly desirable to use it in order to find a solution that suits the legal system best. An example is the interpretation of a uniform international rule codified as domestic law by the national legislature. As uniform international rules have a unifying character, it is rational to observe the interpretation of those rules by other nations. However, it does not follow that it is always the practice of the courts, as the national

\footnotetext{
${ }^{9}$ Case 4/73 J. Nold, Kohlen- und Baustoffgroßhandlung v Commission of the European Communities, [1974], European Court Reports 491, para. 13. Kiikeri remarked that 'this is not only a statement of the static existence of general principles common to the member states, but that, for that matter, it imposes an obligation to follow the development of the case-law of the ECHR and argumentation in these cases and to oversee the development of the national constitutions in this respect. In some ways, it confirms the position of comparative analysis as a dynamic part of the legal sources of the European Community legal system.' Kiikeri, see $n$. 8, at 112.

${ }^{10}$ For example, U.S. CONST. Art. VI, $\S 2$. All Central European nations except Hungary have incorporated international law into their domestic legal orders.
}

${ }^{11}$ Cf. Conforti, International Law and the Role of Domestic Legal Systems (1993) transl. Provost, Martinus Nijhoff Publishers, Dordrecht, at 107-108 (Claiming that 'Subsequent practice' may be derived from judicial precedents from all contracting States and, as such, is especially important with respect to uniform law conventions, given their goal of uniformity.' Yet, Conforti admits that 'the role of comparative law must not be exaggerated. In fact, treaty interpretation relies on subsequent practice as a supplementary element only. It is quite conceivable that foreign precedents could be irrelevant for any number of reasons: because they do violence to the wording of the convention, because they narrowly construe the treaty's object and purpose, or because they tend to give unilateralist answers'). Cf. the 1969 Vienna Convention on the Interpretation of Treaties, Article 31(3b), which states that when interpreting a treaty, there shall be taken into account, together with the context, any subsequent practice in the application of the treaty which establishes the agreement of the parties regarding its interpretation. On the problems relating to the application of these treaties generally, cf. Grosswald Curran, The Interpretive Challenge to Uniformity (1995) 15 Journal of Law and Commerce p. 175.

${ }^{12}$ United Nations Convention on Contracts for the International Sale of Goods (1980), Art. 7(1) In more detail Ferrari, Recent Development: CISG: Specific Topics of the CISG in the Light of Judicial Application and Scholarly Writing (1995) 15 Journal of Law and Commerce p. 1, 8-13 and notes therein.

${ }^{13}$ Air France v. Saks 470 U.S. 392, at 404 (1985) (citation omitted), interpreting the Warsaw Convention for the Unification of Certain Rules Relating to International Transportation by Air, 1929, dealing with the French decision and European scholars. 
law often tends to view those rules as purely national without any comparative aspect from the very moment those rules are implemented in national sources of law. ${ }^{14}$

The family of common law countries, sharing a common conception of law based on its English origins, is an example of comparative interpretation of law shared with other countries. ${ }^{15}$ Common law is an example of the relatively homogenous system of unwritten legal rules, language, values, legal culture, as well as the conception of law as a whole. ${ }^{16}$ Continental micro-groups (like France, Luxembourg, and Belgium, based on revolutionary French codification) also share much more than merely written law, and the shared features include legal mentality, language, legal ideas, doctrines and paradigms. ${ }^{17}$ However, the difference between common law and Continental law traditions should not be neglected, as the Continental system generally tends toward a more national approach to law than the common law system, which causes significant problems in the application of European law.

\section{I.3 Comparative Argumentation in the Application of Law of Purely Domestic Character}

Finally, we can find comparative argumentation of laws of purely domestic character. Apparently, the dividing line between the third and second group is not entirely clear, especially vis-à-vis legal transplants. Here, comparative argument might be considered in an important concrete case.

In integrating Europe, however, the very concept of the law of "a purely domestic character" might be disputed. K.P. Berger assumes that the transformation of comparative law from a branch of legal methodology at the beginning of the twentieth century to becoming a much more substantive tool within the last decades alters the mentality of lawyers and makes them explicitly recognise "that it is today impossible for lawyers to limit their reasoning to the framework of their own domestic system." Such change would have a major influence on the domestic courts within the EU even in fields not governed by EU law:

[T]he domestic courts may no longer remain in domestic isolation by referring to the long standing tradition of their legal system. Instead, they have to take into account the solution found for certain problems by the courts of other EU jurisdictions, even if the case before them involves a legal problem that has not been harmonised by the EU Commission. ${ }^{18}$

\footnotetext{
${ }^{14}$ Drobnig, see n. 4, 11 ff.; Zweigert, Kötz, An Introduction to Comparative Law (Weir transl.) (1998) Oxford: Clarendon Press, at 21 ('when a national judge is faced with a uniform law, he must not simply deploy his trusty old national rules of construction but modify them so as to arrive at an internationally acceptable result which promotes legal uniformity').

${ }^{15}$ Cf. Drobnig's term 'rules shared with other countries', ibid.., at 12 . I prefer call it 'law' rather than simply 'rules.'

${ }^{16}$ Common law seems to be much more 'transnational' than one could expect from the position of a positivistic perspective of a domestic legal order. It possesses a unique 'consciousness that common law is a whole.' Örücü, Comparative Law in British Courts, In: Drobnig and van Erp (eds.), The Use of Comparative Law by Courts (1997) (, , The Hague/London/Boston: Kluwer Law International, at 257. As Örücü rightly points, this temptation is truly unique, and is comparable, perhaps, only to the Islamic legal family. Ibid.

${ }^{17}$ Zweigert, Kötz, see $n .14,101$ ff. Another example might be Scandinavian countries (Peczenik, ON Law and Reason (1989) Dordrecht: Kluwer Academic Publishers) or the Czech and Slovak Republics, both sharing the Czechoslovak legal heritage.

${ }^{18}$ Berger, Harmonisation of European Contract Law, The Influence of Comparative Law, (2001) 50 International and Comparative Law Quarterly p. 877, at 887, emphasis added.
} 
In this sense, no European rule is of a "purely domestic nature." All rules have at least the potential to become "Europeanised", and this deprives national judges of the possibility to refuse to consider foreign law solutions. Members of the Commission of European Contract Law expressly claim in their comparative project, patterned on the American Restatements of the Law, ${ }^{19}$ that their work (Principles of European Contract Law) is "available for the assistance of European courts and legislatures concerned to ensure the fruitful development of contract law on a Unionwide basis." 20

Berger concludes that the process of legal convergence "must lead to a European system of precedents." ${ }^{21}$ Although a critic would say that Berger's appeals for a "European system of precedents" are still more of a wish expressed by European academics than reality in most EU nations, Berger claims that this doctrine might be justified by the principle of equal treatment contained in Art. 21 of the EU Charter of Fundamental Rights as well as the spirit of harmonisation of law "which directs courts in EU Member States to follow precedents rendered by courts in other Member States".22 "Ultimately, a European doctrine of precedents should be an expression of a 'shared-values' approach to the decision of legal disputes which flows from the spirit of European integration." 23

On the other hand, the European rule of precedent in the fields not yet harmonised must be based on a persuasive force of precedent rather than on a formal and binding precedent, because the very idea of transnational judicial conversation presupposes discourse based on the force of reason, not on the force of authority. The European doctrine of precedents opens "the huge stockpile of legal solutions of the courts of the EU Member Countries without interfering with domestic mandatory rules and the dogmatic constraints of their legal systems." 24 However, these constraints are usually flexible enough to encompass a broad circle of various solutions which would fit the living fabric of law within the national system.

\section{I.4 The Role of European Law Prior to Accession}

Where does EU law stand in countries that are not yet member states? Bearing in mind the peculiar nature of the Enlargement, in my opinion, as well as in the opinion of Polish courts, EU law shall be obligatorily considered wherever the domestic law of a candidate country is to be harmonised. As the Supreme Administrative Court in Warsaw put it, the obligation of harmonisation of domestic law with EU law is improperly fulfilled not only through incorrect harmonisation (the problem relating to the national legislature), but also "in cases when the interpretation of internal legal acts by public authorities is contrary to the acquis

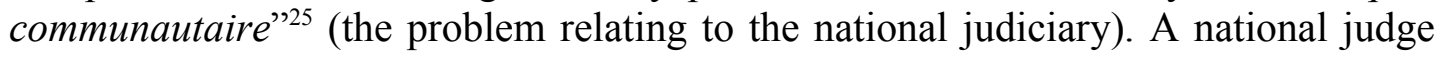

\footnotetext{
${ }^{19}$ Cf. Lando, The Principles of European Contract Law and American Legal Thinking, in: Nafziger \& Symeonides (eds.), Law and Justice in a Multistate World (2002) (.), Transnational Publishers, New York, p. 741-749, at 743.

${ }^{20}$ Lando\&Beale (eds.), Principles of European Contract Law, (2000) Parts I and II., 2nd ed., The Hague, London, Boston: Kluwer Law International, at xxii.

${ }^{21}$ Berger, see n. 18 , at 887

${ }^{22}$ Ibid., at 889 . Berger is dealing with contract law, though I suppose those ideas are not limited only within that area of law.

${ }^{23} \mathrm{Ibid}$, at 892

${ }^{24}$ Ibid., $891 \mathrm{ff}$.

${ }^{25}$ The decision of the Supreme Administrative Court in Warsaw of 13 March 2000 in the case of Senagpo, translated in (1999-2000) 24 Polish Yearbook of International Law p. 217, at 219. The Supreme Administrative Court appealed to the European tax law "as the additional grounds for its judgement." See also a case note by Skrzydło-Tefelska, Ibid., at 220 ("We should welcome with
} 
shall take into account the EU rule corresponding to the national rule (for instance, a directive which has been implemented by the candidate state) including its interpretation by the ECJ or (ideally) also the practice in the EU member states. The Polish Constitutional Tribunal stated this general rule of construction of domestic law:

Of course, EU law has no binding force in Poland. The Constitutional Tribunal wishes, however, to emphasise the provisions of Article 68 and Article 69 of the [Polish Association Agreement] ... Poland is thereby obliged to use 'its best endeavours to ensure that future legislation is compatible with Community legislations' ... The Constitutional Tribunal holds that the obligation to ensure compatibility of legislation (borne, above all, by the parliament and government) results also in the obligation to interpret the existing legislation in such a way as to ensure the greatest possible degree of such compatibility. ${ }^{26}$

The Polish Constitutional Tribunal repeatedly emphasised the principle of Euro-friendly interpretation of national law before European Enlargement. ${ }^{27}$

The demand of Euro-friendly interpretation of domestic legislation in the associated countries confronted post-communist judges with a particularly worrisome problem. In addition to problematic knowledge of EU law, the prevailing old-fashioned concept of due process implies that judges view their activity as primarily mechanical; their decisions even in actual cases resemble exercises in deductive logic, based solely on the binding force of written domestic law. Many home-grown scholars call the legal culture prevailing in Central Europe "the degeneration of legal positivism" or "a dull rule-positivism". ${ }^{28}$ During the most controversial appointment of a new constitutional justice which has ever taken place during Havel's presidency, the appointment of constitutional justice E. Wágnerová in March 2002, President Havel harshly condemned the concept of law that prevailed under post-communism:

It is mechanical, I would like to say senseless, application of law, which almost becomes an object of some cult. ... It is an approach toward the application of law which does not permit any control by ordinary common sense; neither does it allow for any consideration of the law's sense, meaning or circumstances, any consideration of the probable legislative intent or even

\footnotetext{
satisfaction the commented judgement of the SAC since it constitutes the proof that Polish courts have properly understood the obligation of harmonisation of Polish law with the acquis communautaire, which shall be realised not only by initiatives of legal acts consistent with European law but also by the proper interpretation of the existing provisions.").

${ }^{26}$ The Gender Equality in Civil Service Case. In Polish the decision K. 15/97, OTK [Orzecznictwo Trybunalu Konstytucyjnego, the collection of decisions of the Constitutional Tribunal], nr. 19/1997, at 380; English translation 5 East European Case Reporter of Constitutional Law 271, at 284 (1998) (author's emphasis).

${ }^{27}$ According to the Tribunal, this principle is based on Art. 91 (1) of the 1997 Constitution - see the decision K 33/03 of April 21, 2004. Several days after the May 1, 2004 EU Enlargement the Constitutional Tribunal repeated this principle in its landmark decision of May 31, 2004 on the participation of foreigners in the European Parliament $\mathrm{K} \mathrm{15/04}$ (it is possible to find an English summary of both decisions on http://www.trybunal.gov.pl/Eng/).

28 Varga, Transition to Rule of Law. On the Democratic Transformation in Hungary (1995) (Budapest), p. 83, p. 142 respectively.
} 
the core of law's value in a specific case. Although the law is a human product, it attains almost metaphysical authority. ${ }^{29}$

In the legal process perceived in this way, where the judiciary is shackled by the chains of parochial formalism and where mechanical jurisprudence is the only permissible religion, the very concept of soft law as a persuasive authority (such as non-binding EU law having the force of persuasive and substantive argument) is not accorded a warm reception. In the view of mechanical jurisprudence, nothing but a binding source of law (i.e. statute) might be used in the judicial interpretation of law. In this view, law is perfect as it is written, and no loopholes or lacunae exist. Below I will illustrate these problems in the Czech and Slovak judiciary.

\section{EU Law and the Czech courts \\ II.1 The ordinary judiciary}

In the Czech Republic, EU law played a particularly important role in interpreting domestic legislation on competition law. The Czech antitrust authorities took into account EU law in almost every important case. This practice was approved by the Czech High Court in the Škoda Auto case. In this case, the appellant challenged the decision of the antitrust authority, with the argument that EU law was not a binding source of law in the national legal system. The High Court rebuffed this claim, emphasising international links between national antitrust laws:

The protection of free trade is specific in the fact that national law is often not sufficient, and therefore is often enriched by the application of rules used in the countries with a long aged tradition of antitrust law (Germany, USA). For that matter [the Czech antitrust law of 1991] received the basic ideas of the Treaty of Rome, particularly already mentioned Articles 85, 86 and 92; this was from the perspective of harmonisation of the legal systems of the European Communities and the Czech Republic an absolute necessity. ${ }^{30}$

Subsequently the High Court concluded that it was not error of law if the public authority interpreted the Czech antitrust law consistently with the case law of the European Court of Justice and the Commission. The decision of the Constitutional Court validated this approach, emphasising that both the Treaty of Rome and the EU Treaty result from the same values and principles as Czech constitutional law; therefore, the interpretation of European antitrust law by European bodies is valuable for the interpretation of the corresponding Czech rules. ${ }^{31}$

Apart from this field, however, judicial awareness of European law was not high before 1 May 2004 and EU law as an interpretational tool was rarely brought into play. Deep-rooted legislative optimism produces an atmosphere where ordinary judges and lawyers generally overemphasise the impact of legal transplants made by the legislature on the one hand, while seriously understating their own role in that process. That is why one should not be surprised that legal transplants often operate

\footnotetext{
${ }^{29}$ Prague, Senate of the Parliament of the Czech Republic, March 14, 2002, a stenographic record, accessible in Czech on http://www.senat.cz.

${ }^{30}$ The decision of the High Court in Olomouc, November 14, 1996 (Skoda Auto v. Czech Competition Authority), published in (1997) 5 (9) Právní rozhledy p. 484.

31 Škoda Auto Case, Sbírka nálezů a usnesení Ústavního soudu [Collection of decisions of the Constitutional Court, hereinafter 'ÚS'], vol. 8, p. 149. Unlike most decisions of the constitutional courts cited in this article, this decision relates to the constitutional complaint, i.e. review of constitutionality of an individual decision (although of extraordinary importance as it relates to the antitrust penalty for the biggest firm in the country).
} 
in a very different way than in the donor countries. In the systems of limited law and limited sources of law where the idea of persuasive arguments does not exist, a sensible harmonisation is not likely to succeed. The 'anti-European' approach (as well as internationally hostile practice as a whole) of the Czech ordinary courts was also severely criticised by politicians. ${ }^{32}$

This path of limited law was followed by both supreme courts of the former Czechoslovakia. A typical example is the decision of the Slovak Supreme Court of 25 August 1999. In this case the Supreme Court was invited by the parties to consider the fact that the interpretation of the law was contrary to the very EU directive the law was intended to transpose. The Court openly refused to deal with EU law as an argumentative tool to interpret domestic law in a Euro-friendly way. The Court did not distinguish authoritative and persuasive arguments; because in the world of limited law only binding sources exist, anything else is not the law and cannot be used by a court. In the Slovak Supreme Court's view, "considering the current stage of EU integration", an argument based upon a European directive is not relevant. ${ }^{33}$

A Czech counterpart might provide a similar example. In its decision dealing with the validity of an agreement between a consumer and a distributor of expensive pottery, the consumer argued that the agreement was made contrary to sound morals, as the distributor sold him exceptionally expensive pottery under very rigid conditions. The consumer also argued the law of Western countries and European directives and urged the courts to take these into account, as Western European countries, unlike the Czech Republic, have long experience in dealing with consumer agreements. None of the three Czech courts dealing with the issue accepted this invitation to engage in comparative arguments. The Supreme Court based its decision on the quasi-liberal rhetoric of freedom of contract, reminiscent more of the ideas governing European discourse in the mid-nineteenth century than discourse governed by the widely shared necessity to protect the weaker party in negotiation at the outset of the twenty-first century. The Supreme Court did not deal with comparative arguments based on European law. Deciding as the court of final instance, it understood the defendant's arguments as arguments referring to binding sources. That is why it opined:

... the validity of the agreement made between the parties on August 31, 1993 must be decided according to the then valid law, as both lower courts did. In contrast, laws and directives valid in the countries of the European Community are not applicable, as the Czech Republic was not (and still is not) a member of the Communities, and that is why the Czech Republic is not bound by these laws. The binding force of the rules to which the appellant refers cannot be inferred from any provision of the [the Czech Association Agreement], as the court of appeal concluded. The question of harmonisation of the legal practice of the Czech Republic with the legal practice of the European Community gains increasing importance, but this cannot change the outcome of this case. ${ }^{34}$

\footnotetext{
${ }^{32}$ See interview with the former Czech minister of justice Rychetský (since August 2003 the Chief Justice of the Constitutional Court) in the Czech daily Právo, September 25, 2002 (at 1) (noting that few are fully aware that ordinary judges have to deal with the bulk of international law, and after joining EU it will be up to them to ensure the priority of EU law over national law).

${ }^{33}$ The decision published as n. 76 of the Slovak case reporter for 2000: Zbierka stanovísk Najvyššieho súdu a rozhodnutí súdov Slovenskej republiky, hereinafter 'Zbierka' (issue n. 4/2000, p. 55).

${ }^{34}$ The decision of the Czech Supreme Court 25 Cdo 314/99 of December 12, 2000.
} 
To put it clearly, European law in this view can be relevant only when it becomes binding. Because it was obviously not binding in a not-yet EU member state, it was beyond the orbit of the ordinary judiciary until Enlargement was completed. In view of some Slovak and Czech judges, their countries were implementing only texts, and nothing but these texts were used by lawyers in their interpretation.

\section{II.2 The Czech Constitutional Court and EU law}

The Czech Constitutional Court emphasised the special importance of EU law in interpreting domestic law for the first time in the Škoda Auto case. ${ }^{35}$ Since then, the Court has frequently cited the European treaties and the case law of the Court of Justice. European secondary law is also sometimes used, especially if the constitutionality of the harmonising law is challenged before the Constitutional Court. Statutes implementing European directives in EU member states are also cited. ${ }^{36}$

The Constitutional Court emphasised the value of this Euro-friendly approach above all in the review of constitutionality of laws. In a case dealing with the authority of the national government to impose a quota on milk producers, a group of senators questioned the validity of the law. The Constitutional Court denied this argumentation, and proclaimed, inter alia, that certain types of such regulation are permitted also under EU law or GATT. Further, the regulation subject to constitutional review was a step toward approximation with EU law. The petitioners, however, argued that European law was impossible to apply because it was not binding (note here a tension between binding and persuasive sources of law, linking the debate throughout this article). The Court rebuffed this idea, emphasising the existence of general principles of law, common to all EU member states. The content of these principles is formed by common European values; the general principles fill the abstract concept of the state governed by the rule of law including human rights. The Constitutional Court must apply these principles, and thus follow European legal culture and its constitutional traditions. "The primary law of the EU is not a foreign law to the Constitutional Court; it radiates, mainly as the general principles of European law, to a large extent into this Court's adjudication. ${ }^{37}$ In other words - the Czech Constitutional Court refuted the concept of law composed only of binding sources of law and permitted a broader conception.

This approach was also applied in the recent case of quotas for sugar producers. ${ }^{38}$ In its approval of the Czech government's authority to impose quotas on sugar production, the Constitutional Court also referred to Western European policies and the case law of the Court of Justice. ${ }^{39}$ The Court reasoned consequentially:

\footnotetext{
${ }^{35}$ See n. 30 and n. 31 and the accompanying text.

${ }^{36}$ See, for example, the Czech Railway Law Case, published as n. 144/2002 of the Official Gazette "Sbírka zákonů" [hereinafter 'Sb.'] (citing European directives and laws of the EU member states, like the German Federal Railway Law of 1993, the Railway Law of the German länder BadenWürtemberg of 1995, etc.).

${ }^{37}$ Milk Quota Case, published as 410/2001 Sb. Under European law it would be unlikely to consider milk quotas as an example of the general principles of European law. However, it is not entirely clear what these principles are according to the Czech Court - whether the milk quotas themselves or the right to free enterprise (as this right forms the core of European legal culture, the presence of the milk quotas within EU legal order would lead to the conclusion that there is no breach of this right).

${ }^{38}$ Sugar Quota Case, published as 499/2002 Sb.

${ }^{39}$ The comparative range was, however, much wider and also covered extensive treatment of the US Supreme Court's case law.
} 
A Constitutional Court's radical interference with the scheme of production quotas would represent a step towards the concept of nationally guaranteed basic rights; this would conflict with the planned accession of the Czech Republic to the EU.

In contrast, five dissenting justices in two powerful opinions argued that the Czech approach is far more invasive than the European model and, therefore, should have been invalidated. Both the majority and the dissenting justices were in favour of the application of European law, although they differed in the reading of this law and the limits of the national governments in that phase of the accession process. ${ }^{40}$

\section{Some reasons for the disparity of the use of comparative and international law: the difference between the Czecho/Slovak and Polish situation III.1 Slovak and Czech phenomenon: omnipotence of the constitutional courts}

Both the Slovak and Czech constitutional courts in the 1990s substantially changed a deeply rooted concept of law and its application. The courts also achieved this through the application of foreign laws, including considerable inspiration by the decisions of the Court of Justice and the European Court of Human Rights. The constitutional courts have the potential to influence ordinary judges to conceive law in a more material way. On the other hand, as I have indicated, the use of European and international law by the ordinary judiciary was extremely rare prior to the 2004 Accession. ${ }^{41}$ This means that the reception of foreign ideas occurred only on one adjudicative (constitutional) level.

This problem might be illustrated using the example of the application of international law in Central Europe. The Czechoslovak approach after the collapse of the communist regime in 1989 was originally rather unique and only international human rights treaties were incorporated and became the law of the land in 1991. This approach was followed by the Czech and Slovak constitution writers. ${ }^{42}$ International law, save by the constitutional courts, was rarely applied.

In 2001, both the Czech and Slovak republics made international law directly enforceable in their domestic legal systems. The Slovak Constitution, as amended by the constitutional law of $2001,{ }^{43}$ states that international treaties on human rights and basic freedoms, international treaties which can be applied without a statute, and international treaties which deal with rights or duties of natural or legal persons, if ratified and published in the manner stipulated by law, shall have priority over statutes. According to Article 10 of the Czech Constitution, as amended by the socalled "Euro-amendment", ${ }^{44}$ international treaties, whose ratification has been

\footnotetext{
${ }^{40}$ Cf. particularly the dissenting opinion of E. Wágnerová and others in the Sugar Quota Case, see n.40, who argued that the Constitutional Court must fulfil also "an integrating function".

41 The first year of EU membership in both countries has shown that nothing substantial has changed since May 1, 2004.

${ }^{42}$ Professor Eric Stein proposed the general reception of international law for the federal constitution of former Czechoslovakia. See Stein, Czecho-Slovakia, Ethnic Conflict, Constitutional Fissure, Negotiated Breakup (1997) Ann Arbor, at 358, note 10. However, in 1992 both nations, pressed for time, opted for the easier solution and adhered to the Czechoslovak approach of 1991. For more details, see Stein, International Law in Internal Law: Toward Internationalization of Central-Eastern European Constitutions? (1994) 88 American Journal of International Law p. 427.

${ }^{43}$ Art. 7(5), as amended by the constitutional law n. 90/2001 Z.z. The English version of the Constitution as amended in 2001 is accessible on the web page of the Constitutional Court, http://www.concourt.sk.

${ }^{44}$ Constitutional law n. 395/2001 Sb. (in effect since June 1, 2002). The English version of the Constitution as amended in 2001 is accessible on the web page of the Constitutional Court,
} 
approved by the Parliament, and which binds the Czech Republic, are part of the legal order; if an international treaty contains a provision differing from a statute, the former shall be applied. ${ }^{45}$

International law thus takes priority over ordinary statutes (notwithstanding whether enacted earlier or not). However, the firmly established paradigm of centralised constitutional review in Slovakia vested the exclusive prerogative to review any conflict of statutes with international treaties in its constitutional court. ${ }^{46}$ Therefore, ordinary Slovak judges do not have the power to set aside domestic law in conflict with international law and shall refer any such case to the Constitutional Court. It is rather an exceptional position from the comparative perspective. ${ }^{47}$

This seems to develop a further gap between ordinary judges and constitutional courts, and might hinder the potential of ordinary judges who are inclined to distinguish between "them" (constitutional justices, the only judges who adjudicate in an activist way and deal with abstract principles of law), and "us" (ordinary judges, who are supposed to strictly adhere like a machine to the letter of the statute). Therefore, international treaties are not viewed as a common source of law for the public authorities, but rather as something which is a matter of interest only for justices of the Constitutional Court. This did not promote the use of EU law as soft law prior to accession and also did not create good expectations vis-à-vis the application of EU law after accession. It might also cause other problems, such as a further expansion of the Slovak Constitutional Court's already tight docket.

This paradigmatic "Czecho/Slovak" attitude toward centralised constitutional review has been confirmed by the recent Czech case. In contrast with the earlier approach, the Czech Constitution as amended in 2001 implies that both ordinary courts and public authorities have the duty to set aside a domestic statute if the conflict with a ratified international treaty cannot be solved otherwise. This was an important move, as the Czech Constitution as valid prior to 2002 vested exclusive power to control conflicts between international human rights treaties and domestic law in the Czech Constitutional Court. ${ }^{48}$

However, the Constitutional Court, deciding three weeks after the "Euroamendment" to the Constitution had entered into force, ${ }^{49}$ reasoned in dicta against the clear wording of the Constitution and held that the power to adjudicate conflicts between domestic statutes and international human rights treaties was still exclusively vested in the Constitutional Court and each ordinary court must refer these issues to the former court. The Court argued through Art. 9(2) of the Constitution ("eternal" clause providing that basic principles of the rule of law

\footnotetext{
http://www.concourt.cz.

45 Not every treaty requires approval by the Parliament for ratification (Art. 49 of the Czech Constitution) - in the case of such a treaty, Article 10 is not applicable.

${ }^{46}$ In the case of Slovakia, see Art. 125(1)(a) and Art. 144(2) of the Constitution as amended in 2001 and cf. Art. 95(2) of the Czech Constitution until 2002 (and subsequent reading of this article by the Constitutional Court).

${ }^{47}$ In countries where international treaties have been incorporated into the domestic system, the ordinary courts ensure the application of international treaties and, in the case of conflicts between the treaty and the statute, set aside the latter and apply the former. In Germany, Italy or the United States it is subject to the principle of lex posterior, while in the Netherlands, France, Belgium etc. the treaty takes priority over both prior and posterior statutes. Cf. generally Cassese, Modern Constitutions and International Law, (1985) 192 (III) Recueil des Cours 330.

${ }^{48}$ See Art. 87(1) (a) of the Constitution of the Czech Republic until June 1, 2002.

${ }^{49}$ The decision of June 25, 2002, published as n. 403/2002 Sb. (the case of constitutionality of the Bankruptcy law).
} 
cannot be changed even by constitutional amendment ${ }^{50}$ ) and concluded that transfer of the power to set aside the law to ordinary courts would impair the constitutional protection of human rights, which is with regard to Art. 9(2) not acceptable. It is interesting how alleged differences between common law and Continental law might work even in the brains of quite sophisticated constitutional justices and how these differences might be held irreversible. In a system without a binding judicial precedent, the Court argued, only a centralised system of judicial review might work. In other words, the Czech Constitutional Court entrenched centralised judicial review (supposedly only vis-à-vis human rights), because the Court reserved exclusively for itself and forever to decide on any conflict between international human rights issue and domestic law.

The real, although not disclosed, rationale of the Czech Constitutional Court's approach is easy to detect. This is the fear of the Constitutional Court that if the issue of international law were beyond its reach, international treaties, considering the opinions inside the ordinary judiciary, would rarely be applied. As I have already shown, the application of international law is obviously contrary to the deeply entrenched ideals of textual positivism in the region. Facing this dreadful situation, one would be very prone to concede that the Czech Constitutional Court's decision not to give up its power and save the application of international treaties was reasonable. What is worrisome, however, is the fact that the Constitutional Court openly resigned from the idea that the ordinary courts would ever be able to apply international law and set aside municipal law for its conflict with an international treaty. This does not promote the use of EU law following European Enlargement. The ECJ's role in interpreting the community law is not an equivalent of the constitutional tribunal in a rigidly centralised system; moreover, the current trend of the ECJ's adjudication seems to give even more discretion to the national judges. ${ }^{51}$ Therefore, with the decentralised review of national legislation on its conformity with European law, the current Czecho/Slovak ideology of textual positivism and rigid adherence to the text of domestic law, including the rigid adherence to centralised judicial review, ${ }^{52}$ will suffer a serious backlash.

\section{III.2 The case of Poland: a mixed system of centralised and decentralised constitutional review}

The Polish situation and application of international and European law seemed to be more encouraging. ${ }^{53}$ Already in 1995 the Supreme Court proclaimed

\footnotetext{
${ }_{50}$ The Czech eternal clause, unlike its German counterpart, does not enumerate these entrenched principles.

${ }^{51}$ Tridimas, Enforcing Community Rights in National Courts: Some Recent Developments, In: David O’ Keeffe (ed.), Judicial Review in European Union Law. Liber Amicorum in Honour of Lord Slynn of Hadley (2000)), Kluwer, p. 465, at 466 (noting that at the European Court of Justice there is 'the tendency of the case-law to leave discretion to national courts in determining whether the national rules of procedure provide a sufficient level of protection for Community rights in issue.').

${ }^{52} \mathrm{Cf}$. Comella, The European model of constitutional review of legislation: Toward decentralization? (2004) 2 Int'l J. of Constitutional Law p. 461. This author claims that the centralised model of constitutional review seems to be in crisis, facing both internal and external problems.

${ }^{53}$ Cf. see n. 8-9 and accompanying text. See, further, for example, Leszczyński, Application of the European Convention in the Polish Courts: An Impact on the Judicial Argumentation, (1996) 2 East European Human Rights Review p. 19, 37 (characterising the change of judicial attitude toward the Convention as "the strenuous process of shaping the attitude according to which the court would be able to directly implement the international law of Human Rights in its decisions"); Wyrozumska, Impact of the case-law of the organs of the European Convention on Human Rights on domestic law and the national judge, In: Council of Europe, The judge and international law, Multilateral meeting Bucharest, 28-30 November 1994 (Strasbourg 1998), p. 139, 149 ff. (citing numerous examples of the
} 
that "since Polish accession to the Council of Europe the case-law of the European Court of Human Rights in Strasbourg may and should be taken into consideration to interpret the provisions of the Polish law. ${ }^{, 54}$ A similarly open attitude existed vis-àvis EU law. ${ }^{55}$

The apparent difference between the Polish and Czech judiciary might be due to the fact that in Poland, unlike the Czech Republic, the Constitutional Tribunal was weaker in relation to the ordinary judiciary and has never been omnipotent. Therefore, the ordinary judiciary, particularly the Supreme Court, had greater responsibility in human rights protection. Further, the Polish courts had much more experience in treaty application, including in the era of communist rule. ${ }^{56}$ Further, and even more importantly, the judicial activism of the Polish courts has always appeared much stronger than the activism of the Czecho/Slovak courts. ${ }^{57}$ Not only did the Polish ordinary courts use their power to set acts of parliament aside, they also tried to interpret them consistently with international treaties. ${ }^{58}$

Last but not least, the more activist ordinary courts of Poland were able to retain their power to set aside the law in conflict with international treaty. In doing so, the judges of ordinary courts argued by the Constitution of 1997, which provides that "[a]ny court may refer a question of law to the Constitutional Tribunal as to the conformity of a normative act with the Constitution, ratified international agreements or statute, if the answer to such question of law will determine an issue currently before such court." 59 This article read by ordinary judges established their judicial discretion whether to refer the issue to the Constitutional Tribunal. While the question of whether ordinary judges have this right in relation to the Constitution is highly controversial, the competence of the Polish ordinary courts to set aside the law for its conflict with international treaty (either prior or posterior to the law) has never been seriously questioned (in spite of the possible alternative reading of Art. $193){ }^{60}$

Polish Supreme Court's case law even before the Convention had become the law of Poland); Wyrozumska, Direct Application of the Polish Constitution and International Treaties to Private Conduct (2001) 25 Polish Yearbook of International Law p. 5, hereinafter 'Direct Application' (citing judicial decisions of the Supreme Court applying international treaties, European law and the constitution in a horizontal way).

${ }^{54}$ The Court's main rationale was not strictly legal, but, as the Court itself admitted, was rather based on "the Polish interest of not being criticised by the European Court of Human Rights or doctrine of international law or even popular newspapers." Wyrozumska, Impact of the case-law of the organs of the European Convention on Human Rights on domestic law and the national judge, see n.39, at 150, citing the decision of the Supreme Court of January 11, 1995.

${ }^{55}$ For many examples, see Czapliński, Harmonisation of Laws in the European Community and Approximation of Polish Legislation to Community Law (2001) 25 Polish Yearbook of International Law p. 45, $55 \mathrm{ff}$.

${ }^{56} \mathrm{Cf}$. Wyrozumska, Direct Application, see n.53, at 23, emphasising this historical aspect.

${ }^{57}$ The Polish courts were more inclined than their Czechoslovak counterparts to apply international law before the 1990s; e.g. Skubiszewski, Poland's Constitution and the Conclusion of the Treaties (1957) 7 Jahrbuch für Internationales Recht p. 213, 222 ff.; Skubiszewski, Glosa do postanowienia z 25 VIII 1987, I PRZ 8/87, Umowy międzynarodowe w porzadku prawnym PRL [A note to the decision of 8/25 1987, I PRZ 8/87, International Treaties in the legal order of the People's Republic of Poland], (1989) 44/6 Państwo i Prawo p. 135; Czapliński, International Law and Polish Domestic Law, in: Müllerson, Fitzmaurice, Andenas (eds.), Constitutional Reform and International Law in Central and EASTERN EUROPE (1998) Kluwer 1998.

${ }^{58}$ Cf. the decision of the Supreme Administrative Court of Poland of August 26, 1999 (V S.A. 708/99), interpreting the Aliens Act consistently with the Geneva Convention on Refugees (translated in (1999-2000) 24 Polish Yearbook of International Law, p. 223).

${ }^{59}$ Art. 193 (author's emphasis).

${ }^{60}$ Wyrozumska, Direct Application, see n.53, at 23. 


\section{Conclusion}

The association agreements with the post-communist nations aspiring to join the EU put immense burdens on their changing legal systems. A complex process of harmonisation of domestic law with the acquis communautaire is a major challenge to the immature legal orders of Central Europe. It would be futile to put all the energy relating to this process only on the national legislature. On the contrary, the ultimate success of harmonisation depends on the judiciaries of the candidate states. Their judges have to adjudicate with the goal of an integrated Europe in mind. After all, that is why many scholars claim that there is not only one European Court, but in fact thousands of European courts, dispersed throughout the territory of the EU. ${ }^{61}$

In Central Europe, it means extending the legal discourse and leaving some deeply rooted assumptions about the law. International and European discourse must involve ordinary judges. The European legal culture is by its very nature inclusive. If all judges of the candidate countries acted as if they already were European judges, the first day after EU enlargement would not mean a legal revolution annihilating entirely the philosophy of the old system; on the contrary, this would mean a mere continuation of the process already started by the association treaties. And even more importantly, if we maintain that EU law shall be obligatorily considered wherever the domestic law of a candidate country is to be harmonised, we might reach the point where not the texts but rather the laws are being harmonised.

${ }_{61}$ This is the primary idea of Slaughter, Sweet, Weiler (eds.), The European Court and National Courts - Doctrine and Jurisprudence (1998) Oxford. 